\title{
Development of Interactive Flash Media in Learning Newton's Laws
}

\author{
A.Zaky Al-Ghozali ${ }^{1}$, Dwi Yulianti ${ }^{2}$, Undang Rosidin ${ }^{3}$ \\ Master of Educational Technology, Faculty of Teacher Training and Education, \\ University of Lampung
}

\begin{abstract}
This study aims to develop and determine the feasibility of interactive flash media in Newton law learning using a research and development model with ADDIE (Alaysis, Design, Development, Implementation, and Evaluation) development methods. Interactive flash media in learning Newton's laws is validated by material experts and media experts, and trialled in small group trials and field trials. Data collection techniques using observation and questionnaires. The research instrument used was a structured questionnaire using a Likert scale. Data analysis technique is descriptive. The results of this research and development of interactive flash media are categorized as appropriate to be used as learning media in learning Newton's laws of natural science subjects. This can be seen from the results of the assessment of material experts worth 3.75 feasible categories, media experts worth 4.12 feasible categories, small group trials worth 3.01 feasible categories, and field trials worth 3.27 very decent categories. So get a total average score of 3.54 which is included in the feasible category.
\end{abstract}

Keywords:- Development; Interactive; Flash Medial; Newton's Laws.

\section{INTRODUCTION}

Newton's laws are one of the materials in the Natural Sciences (IPA) subjects that were studied in class VIII of junior high school. Based on preliminary observations and from the needs analysis questionnaire data at SMP NU Bumi Rahayu, the following information was obtained:

\begin{tabular}{|l|l|l|l|}
\hline No & Value & $\begin{array}{l}\text { Total } \\
\text { Students }\end{array}$ & $\begin{array}{l}\text { Percentage } \\
(\%)\end{array}$ \\
\hline 1 & Value $\geq$ KKM & 9 students & $34.62 \%$ \\
\hline 2 & Value $<$ KKM & 17 students & $65.38 \%$ \\
\hline
\end{tabular}

Table 1:- Percentage of Daily Replications in Material

Newton Law Class VIII Academic Year 2018/2019

Information :

$\mathrm{KKM}=$ Minimum completeness criteria (75)

\begin{tabular}{|c|c|c|}
\hline Question No. & Average score & Category \\
\hline 1 & 1.00 & Agree \\
\hline 2 & 1.00 & Agree \\
\hline 3 & 1.00 & Agree \\
\hline 4 & 1.00 & Agree \\
\hline 5 & 1.00 & Agree \\
\hline 6 & 1.00 & Agree \\
\hline 7 & 1.00 & Agree \\
\hline 8 & 0.65 & Strongly agree \\
\hline 9 & 0.00 & Strongly agree \\
\hline 10 & 0.00 & Strongly agree \\
\hline
\end{tabular}

Table 2:- Results of Questionnaire Analysis of Student Needs

Question :

$>$ Natural science subjects are difficult to understand

$>$ The low student interest in learning about science subjects

$>$ Learning Newton's laws are less interesting to learn

$>$ Low student learning outcomes on the subject of Newton's Laws

$>$ Often learning only uses conventional methods

$>$ The learning process is monotonous

$>$ Student activity in class decreases

$>$ Often the teacher gives assignments to students

$>$ The limitations of learning media as a support for understanding the material

$>$ The teacher has not yet developed interactive learning media

Based on observational data and the results of the questionnaire above, it can be concluded that science subjects are difficult to understand because of the low student interest in studying science subjects and learning Newton's laws are less interesting to learn which results in low student learning outcomes on the subject of Newton's Laws. Often learning only uses conventional methods so the learning process is monotonous and the activeness of students in the class also decreases. Often teachers give assignments to students because of the limitations of learning media as a support for understanding the material, and teachers have not yet developed interactive learning media. 
Muslich (2007: 221) suggests that many natural science teachers use learning time by discussing past assignments, giving new lessons, giving assignments to students, and often teachers deliver material using conventional methods. Learning as above can be categorized as $3 \mathrm{M}$, boring, dangerous, and damaging student interest. Based on this opinion, efforts to correct weaknesses in the existing learning process, one of them is by making interactive learning media. Djamarah and Zain (2010: 120) suggest that in the learning process the unclear material delivered can be helped by presenting the media as an intermediary.

According to Arsyad (2011: 3), the word media comes from the Latin medius which literally means middle, intermediary or introduction. In Arabic the media is an intermediary or introduction to the message from the sender to the recipient of the message. Furthermore according to Munir (2009: 88) states that, in the process of interactive learning, there are several forms of communication, namely one way (one way communication) and two ways (two ways communication), and many directions (multy ways communication) takes place between the instructor and student. Teachers deliver learning material and students provide responses (response) to the material. Opinions from the two experts above can be described that interactive learning media are the intermediaries of learning used in learning and therein interaction occurs between students and teachers, students and students, and students with learning media used to achieve learning objectives.

The use of interactive learning media used by teachers aims to enable students to learn actively. According to Latuheru (1988: 23) the benefits of learning media are:

$>$ learning media attracts and enlarges the attention of students towards the teaching material presented.

$>$ learning media reduces, can even eliminate the existence of verbalism.

$>$ learning media overcome differences in learning experiences based on socioeconomic backgrounds of students.

$>$ learning media helps provide learning experiences that are difficult to obtain in other ways.

$>$ learning media can overcome the problem of boundaries of space and time.

$>$ learning media can help students develop their minds regularly about the things they experience.

$>$ learning media can help students in overcoming things that are hard to see with their eyes.

$>$ learning media can foster the ability to work alone based on experience and reality.

$>$ learning media can overcome things / events / events that are difficult to be followed by the senses of the eye.

$>$ learning media allows for direct contact between students, teachers, with the community, and with the natural environment around them.

The use of media in learning provides benefits for both teachers and students. Through the use of media, teachers have adequate facilities or tools to deliver lessons. Conversely for students, the use of media can make students overcome boredom and saturation when receiving lessons. Through learning media, it is hoped that teachers will become more creative and innovative in providing learning to students. Making interactive flash media in this study using the Adobe Falsh Professional CS 6 application. According to Madcoms (2012: 2), Flash is an application program for creating various animations such as, animated cartoons, web, movies, presentations, company profiles, ecards and the game with the results of a lightweight file that is easily accessed without requiring a long time. Adobe Flash Professional CS 6 was released in 2012 which uses a programming language called Action Script that first appeared in Adobe Flash CS 5. The Action Script in Adobe Flash Professional CS 6 makes presentations or learning media more varied and of course will be more interesting compared to other presentation programs or media.

Based on the above problems, one of the factors that can change the conventional learning system is by developing interactive flash media as a science learning media. the ability and creativity of science teachers in Bumi Rahayu NU Middle School in making or developing learning media is still limited. On the basis of consideration of the results of the analysis of student needs analysis, archives of the daily test list, and the problems mentioned above, the researcher tried to develop learning media through a study entitled "Development of Interactive Flash Media in Learning Newton's Laws."

The purpose of this research is to develop and know the feasibility of interactive flash media in learning Newton's laws. This research is expected to be able to add alternative instructional materials used by teachers to improve better learning and optimize student understanding of Newton's law material, help students learn to be independent and be able to increase motivation, creativity, and student curiosity, increase ability and understanding of Newton's law material, as a material consideration in implementing the development of instructional media, especially on science subjects, and as material information about learning media.

\section{METHOD}

\section{A. Type of Research}

The development model used in this study is the type of research and development or Research and Development (R\&D). According to Sugiyono (2015: 530), Research and Development (R\&D) is a type of research used to produce a product. The product of this research is a learning media in the form of flash-based graphics and graphics for learning Newton's laws in eighth grade students of SMP which are packaged in a $C D$.

\section{B. Place and Time of Research}

The research was conducted in class VIII of Bumi Rahayu NU Middle School which was carried out in the seminary semester, namely October-December 2019/2020 academic year on newton law material. 


\section{Research Subjects and Objects}

The subjects of this study were 23 students of class VIII of NU Bumi Rahayu Middle School. While the object of this research is interactive flash media in learning Newton's laws.

\section{Research Design}

The method used in this study uses the ADDIE development model. According to Branch (2009: 2), ADDIE is an abbreviation of Alaysis, Design, Development, Implementation, and Evaluation. The following is a picture of the stages of $R \& D$ research steps using the ADDIE approach.

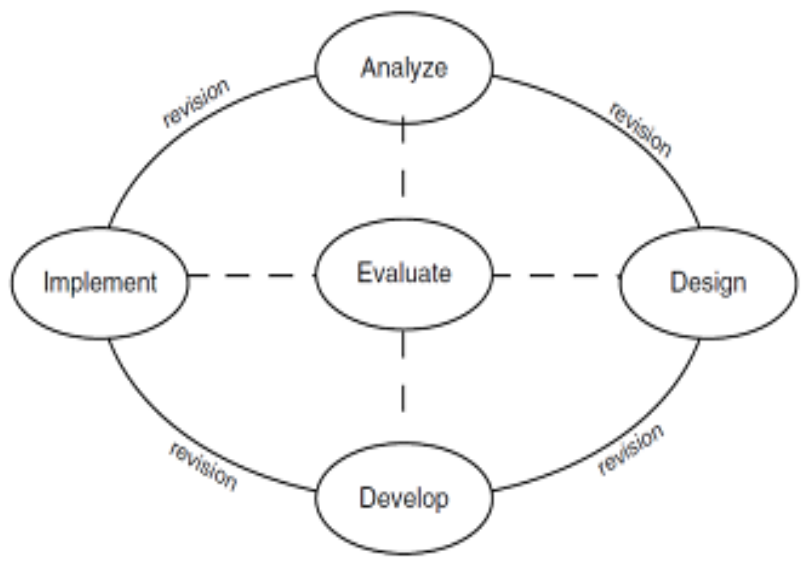

Fig 1:- Steps of R\&D Research using the ADDIE approach According to Branch (2009: 2)

\section{E. Data Collection Techniques}

Data collection techniques can be done with interviews (interviews), questionnaires (questionnaire), observation (observation) and a combination of the three. (Sugiyono, 2015: 309).

The research instrument used was using a structured questionnaire using a Likert scale that would be filled by material experts and media experts (validators) and students (research subjects) by giving a check mark $(\checkmark)$ in the answer column. The main principle in the Likert scale is to determine the location of one's position, ranging from very negative to very positive (Widoyoko, 2014: 115). The scale used for the assessment of material experts and media experts consists of 5 assessment categories as in table 3 .

\begin{tabular}{|c|c|}
\hline Category & Score \\
\hline Very Good (SB) & 5 \\
\hline Good (B) & 4 \\
\hline Enough (C) & 3 \\
\hline Less (K) & 2 \\
\hline Very Poor (SK) & 1 \\
\hline
\end{tabular}

Table 3:- Guidelines for Reporting Expert Validation Results (Widoyoko, 2014)
While the scale used for student responses consists of 5 assessment categories as in table 4 .

\begin{tabular}{|c|c|c|}
\hline \multirow{2}{*}{ Category } & \multicolumn{2}{|c|}{ Score } \\
\cline { 2 - 3 } & $\begin{array}{c}\text { Positive } \\
\text { Statement }\end{array}$ & $\begin{array}{c}\text { Negative } \\
\text { Statement }\end{array}$ \\
\hline Strongly Agree (SS) & 4 & 0 \\
\hline Agree (S) & 3 & 1 \\
\hline Hesitation (R) & 3 & 2 \\
\hline Disagree (TS) & 1 & 3 \\
\hline Strongly Disagree (STS) & 0 & 4 \\
\hline
\end{tabular}

Table 4:- Scoring Guidelines for Student Response Questionnaire Results (Widoyoko, 2014)

\section{F. Data Analysis Techniques}

Data analysis was performed to process quantitative data in this study. In general, the data analysis stage of the questionnaire results obtained was calculating the average score in accordance with the scoring guidelines of each aspect and then converted to qualitative criteria by referring to the guidelines in table 5. (Widoyoko, 2014: 238).

\begin{tabular}{|c|c|}
\hline Interval & Category \\
\hline$M i+1,8 S B i<\bar{x}$ & Very decent \\
\hline$M i+0,6 S B i<\bar{x} \leq M i+1,8 S B i$ & Worthy \\
\hline$M i-0,6 S B i<\bar{x} \leq M i+0,6 S B i$ & Decent enough \\
\hline$M i-1,8 S B i<\bar{x} \leq M i-0,6 S B i$ & Inadequate \\
\hline $\bar{x} \leq M i-1,8 S B i$ & Very Inadequate \\
\hline
\end{tabular}

Table 5:- Converting Scores into Values on a Scale of 5 Interval Category (Widoyoko, 2014)

Keterangan :

$\overline{\mathrm{x}}=$ average acquisition score

Mi $($ middle value $)=\frac{1}{2}($ Ideal max score + Ideal min score $)$

$\mathrm{SBi}$ (Ideal standard deviation) $=\frac{1}{6}$ (Ideal max score - Ideal min score)

Ideal max score $=$ highest score

Ideal $\min$ score $=$ lowest score

\section{Expert Assessment Analysis}

In this assessment, the ideal maximum score is 5 and the minimum score is 1 so that the determination of the assessment criteria interval refers to table 5. More details can be seen in table 6 .

\begin{tabular}{|c|c|}
\hline Interval & Category \\
\hline $4,2<\overline{\mathrm{x}}$ & Very decent \\
\hline $3,4<\overline{\mathrm{x}} \leq 4,2$ & Worthy \\
\hline $2,6<\overline{\mathrm{x}} \leq 3,4$ & Decent enough \\
\hline $1,8<\overline{\mathrm{x}} \leq 2,6$ & Inadequate \\
\hline$\overline{\mathrm{x}} \leq 1,8$ & Very Inadequate \\
\hline
\end{tabular}

Table 6:- Classification of Value of Expert Validation Results (Widoyoko, 2014)

The media is said to be valid if the average score obtained by the validator is in the feasible or very feasible category. 
Analysis of Student Responses

In the student response questionnaire, the ideal maximum score was 4 and the minimum score was 0 . Determination of the interval of the assessment criteria of students' responses to the media refers to table 5. More details can be seen in table 7 .

\begin{tabular}{|c|c|}
\hline Interval & Category \\
\hline $3,2<\overline{\mathrm{x}}$ & Very decent \\
\hline $2,4<\overline{\mathrm{x}} \leq 3,2$ & Worthy \\
\hline $1,6<\overline{\mathrm{x}} \leq 2,4$ & Decent enough \\
\hline $0,8<\overline{\mathrm{x}} \leq 1,6$ & Inadequate \\
\hline$\overline{\mathrm{x}} \leq 0,8$ & Very Inadequate \\
\hline
\end{tabular}

Table 7:- Classification of Value of Student Response Results (Widoyoko, 2014)

The media is said to be feasible if the acquisition of an average score from the questionnaire responses of students included in the category of feasible or very decent.

\section{RESULT AND DISCUSSION}

The stages in developing interactive flash media on learning Newton's laws are:

\section{A. Analysis}

The results of the analysis are used as a reference in developing learning media.

\section{$>$ Analysis of student needs}

Based on observational data and the results of the questionnaire it can be concluded that science subjects are difficult to understand because of the low student interest in studying science subjects and learning Newton's laws are less interesting to learn which results in low student learning outcomes on the subject of Newton's Laws. Often learning only uses conventional methods so the learning process is monotonous and the activeness of students in the class also decreases. Often teachers give assignments to students because of the limitations of learning media as a support for understanding the material, and teachers have not yet developed interactive learning media.

\section{Curriculum Analysis}

At SMP NU Bumi Rahayu the curriculum applied was the 2013 curriculum.

\section{Learning Media Analysis}

The learning process in NU Bumi Rahayu Middle School, teachers only use makeshift media, such as print media (pictures) and simple demonstrations. So that the media is not interactive (does not require interaction from students on learning media) so that makes students tend to be bored and bored in following the learning process in class.

Based on the results of the analysis as a reference in developing learning media, the researcher wants to develop interactive flash media in learning Newton's laws.

\section{B. Design}

At this stage the researcher makes a draft media concept that will be created. The design phase (design) is a research phase which contains a learning media framework, which aims to get an interactive learning media.

\section{$>$ Flowchart}

Flowchart is a learning media flow in a nutshell. A flow chart is a graphical depiction of the steps and sequences of procedures of a program. Flowchart on interactive flash media in learning Newton's law can be seen in Figure 2.

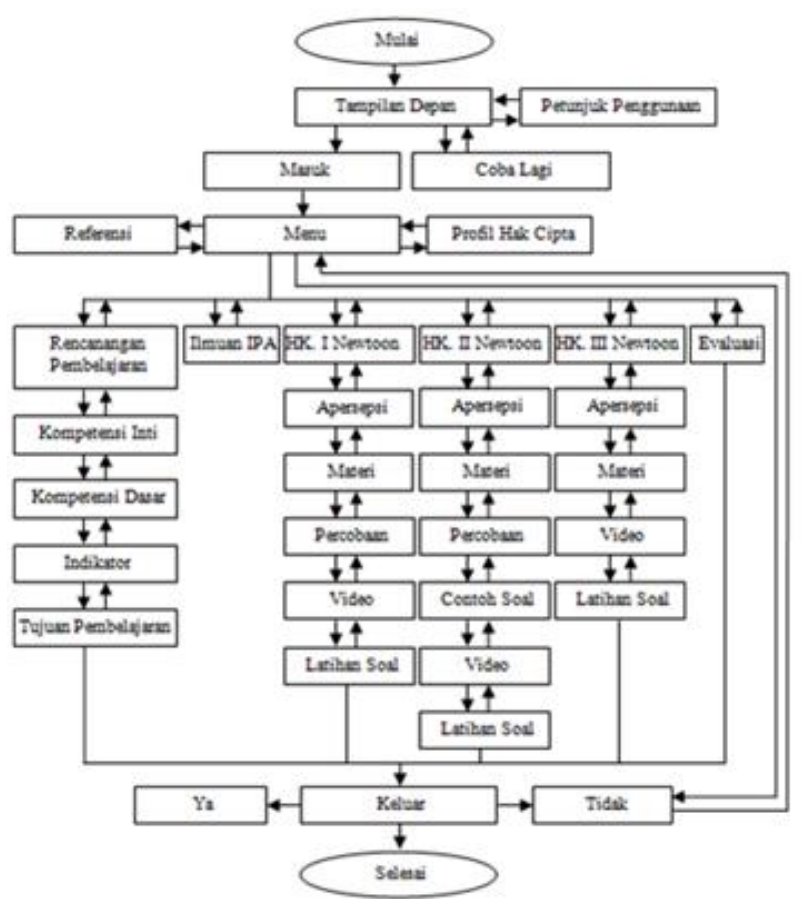

Fig 2:- Flowchart (flow diagram) interactive flash media in learning Newton's laws

\section{Storyboard}

A storyboard is a sketch of an image created to simplify the design and make it easier to illustrate the storyline through the images presented. This storyboard can be seen in Figure 3-7.

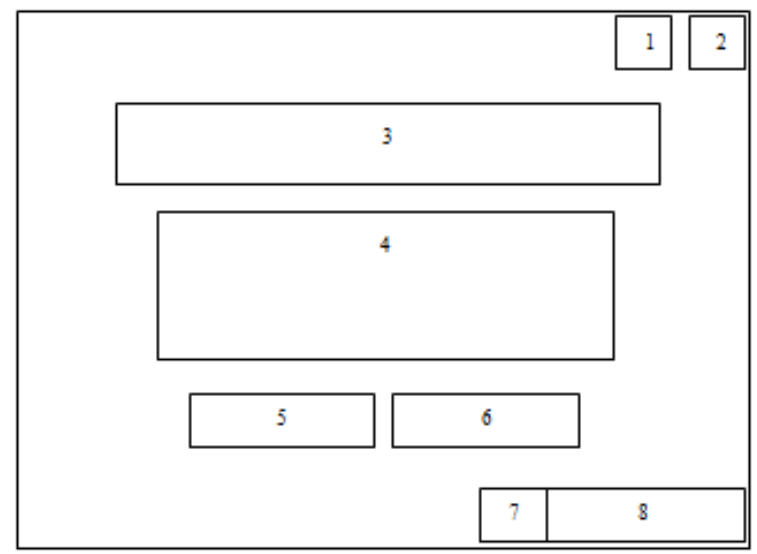

Fig 3:- Storyboard intro menu view (opening) 


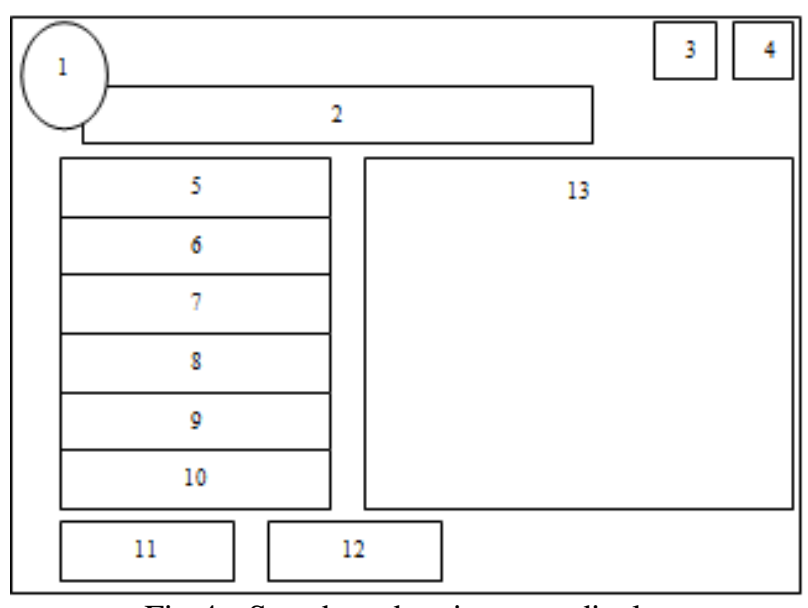

Fig 4:- Storyboard main menu display

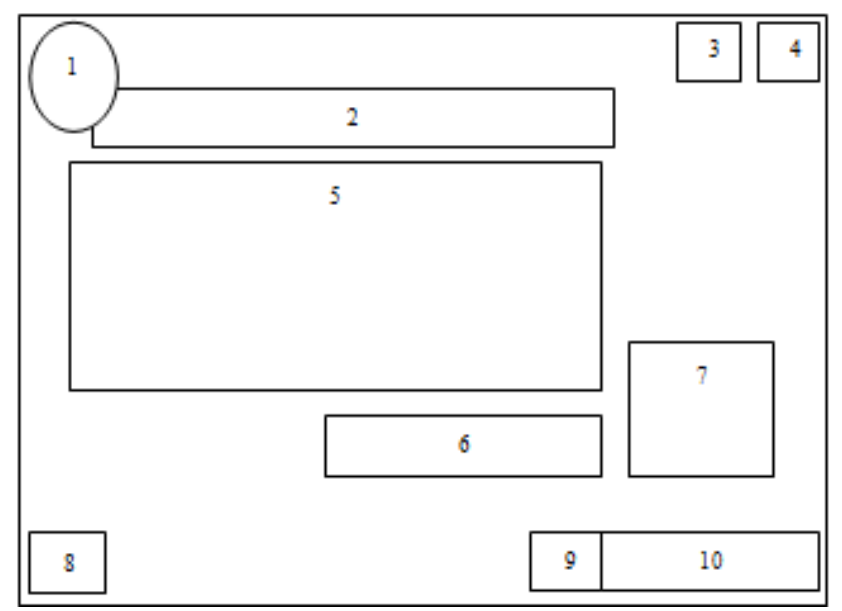

Fig 5:- Storyboard for initial evaluation

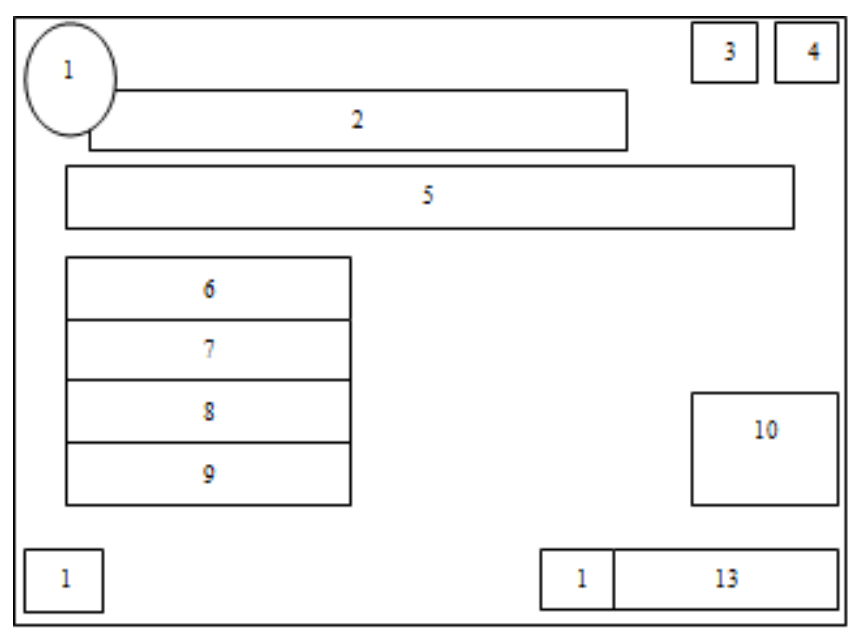

Fig 6:- Storyboard evaluation view

ISSN No:-2456-2165

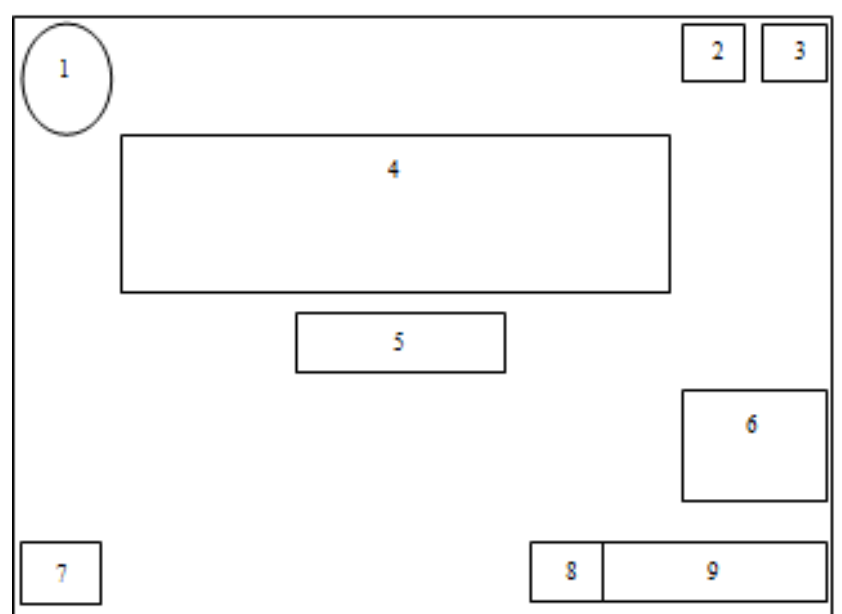

Fig 7:- Storyboard display response response evaluation

\section{Development}

After designing the media concept, the next step is the media development stage.

\section{Making learning media}

Making interactive flash media in learning Newton laws using Adobe Flash Professional CS 6. The learning media is adapted to the concepts that have been designed.

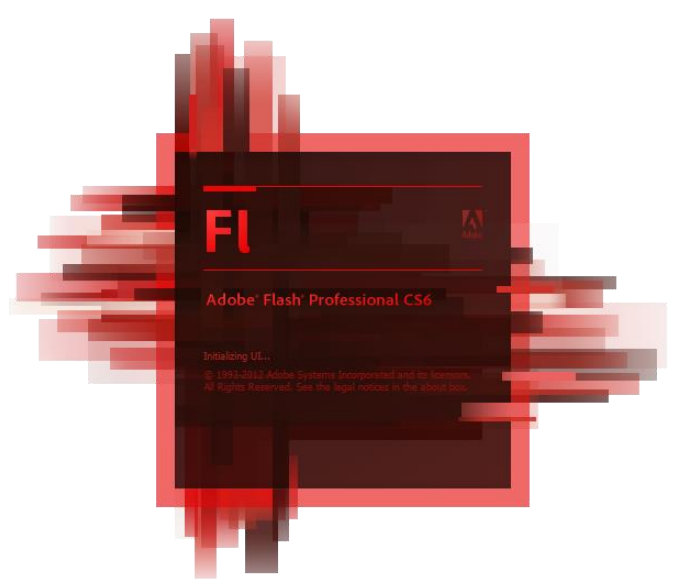

Fig 8:- Adobe Flash Professional CS 6 application

\section{Design Validation}

Validation is carried out by 2 material experts who master the field of competency being studied and 2 media experts who master the field of media. This validation aims to determine the feasibility of media that have been developed.

\section{- Material Expert}

Based on the evaluation results on 2 material experts consisting of 18 items, the mean score of the assessment indicators obtained the lowest score of 3.0 and the highest score of 4.0 from the maximum score of 5.0 while the average number of scores for each item was 67.00. So, the average total score $\frac{67.00}{18}=3.75$ of the maximum score of 5.0, so that it is included in the "decent / good" category. 


\section{- Media Expert}

Based on the evaluation results on 2 media experts consisting of 18 items, the mean score of the assessment indicators obtained the lowest score of 3.5 and the highest score of 5.0 from the maximum score of 5.0 while the average number of scores of each item was 74.50. So, the average total score of $\frac{74.5}{18}=4.12$ from the maximum score of 5.0, so that it falls into the "decent / good" category.

\section{Media Revision}

Media that has been validated by the validator is then revised according to the input and suggestions at the time of media validation.

\section{- Material Expert}

The suggestions from material experts related to the learning media developed are in table 8 and table 9.

\begin{tabular}{|c|c|}
\hline No & Suggestion \\
\hline 1 & Need to increase the efficiency of usage time \\
\hline 2 & Operations need to be simplified \\
\hline 3 & Not yet described the concept clarity \\
\hline
\end{tabular}

Table 8:- Expert Advice on Material 1

\begin{tabular}{|c|c|}
\hline No & Suggestion \\
\hline 1 & $\begin{array}{c}\text { The core competencies displayed are KI 3 and KI 4, } \\
\text { as well as basic competencies }\end{array}$ \\
\hline 2 & $\begin{array}{c}\text { Newton's I, II, and III legal experiments were } \\
\text { replaced by videos with the same intent and } \\
\text { purpose }\end{array}$ \\
\hline 3 & $\begin{array}{c}\text { Exercise questions on Newton's laws I, II, and III } \\
\text { are deleted, add the questions to the evaluation } \\
\text { section }\end{array}$ \\
\hline
\end{tabular}

Table 9:- Expert Advice on Material 2

\section{- Media Expert}

Suggestions As for suggestions from media experts related to the learning media that are developed are found in tebel 10 and table 11 .

\begin{tabular}{|c|c|}
\hline No & Suggestion \\
\hline 1 & $\begin{array}{c}\text { There are several points that must be revised, giving } \\
\text { examples of the material in editing from the results } \\
\text { of the researchers own video capture }\end{array}$ \\
\hline 2 & $\begin{array}{c}\text { The design of learning should be adjusted to the } \\
2013 \text { curriculum that directs scientific learning } \\
\text { (based on the resulting lab work) }\end{array}$ \\
\hline
\end{tabular}

Table 10:- Media Expert Advice 1

\begin{tabular}{|c|c|}
\hline No & Suggestion \\
\hline 1 & $\begin{array}{c}\text { Simplify the start page, or directly create a welcome } \\
\text { display }\end{array}$ \\
\hline 2 & The instructions for using media are clarified \\
\hline 3 & Backsound is replaced by instrument music \\
\hline 4 & $\begin{array}{c}\text { The user's identity column was moved before } \\
\text { evaluation }\end{array}$ \\
\hline
\end{tabular}

Table 11:- Media Expert Advice 2

\section{Implementation}

After the developed media has been prepared and declared to be suitable for use in class by material experts and media experts, the media will then be tested in schools that have been determined as research sites. The media was tested on students who were the subject of research, namely class VIII. The trials consisted of small group trials and field trials.

\section{- Small Group Trials}

A small group trial was conducted on students of class VIII of SMP NU Bumi Rahayu randomly. so that a sample of 5 out of 23 students was obtained. Small group trials focus on students' responses to learning media based on suggestions and input from students.

Based on the evaluation results on 5 students consisting of 17 items, the mean score of the assessment indicators obtained the lowest score of 2.6 and the highest score of 3.8 from the maximum score of 4.0 while the average number of scores for each item was 51.20. So, the average total score of $\frac{51.20}{17}=3.01$ of the maximum score of 4.0, so that it falls into the "decent / good" category. The criticisms and suggestions from 5 students in a small group trial related to the learning media that were developed are in table 12 .

\begin{tabular}{|c|c|c|}
\hline No & Respondents & Suggestion \\
\hline 1 & Student 1 & $\begin{array}{c}\text { Add sound to the welcome } \\
\text { display, learning design, science } \\
\text { scientists, and user identity }\end{array}$ \\
\hline 2 & Student 2 & $\begin{array}{c}\text { The instructions for using media } \\
\text { are incomplete }\end{array}$ \\
\hline 3 & Student 3 & $\begin{array}{c}\text { The exit button from the learning } \\
\text { media is too complicated }\end{array}$ \\
\hline 5 & Student 4 & Add dates to the learning media \\
\hline 5 & Student 5 & $\begin{array}{c}\text { The video navigation button on } \\
\text { the main menu display should } \\
\text { not be hidden }\end{array}$ \\
\hline
\end{tabular}

Table 12:- Suggestions for Small Group Trials

\section{- Field Trial}

After the revision process was carried out according to the suggestions of 5 students in a small group trial, then a field trial was conducted. The field trial was conducted on 23 grade VIII students of SMP NU Bumi Rahayu.

Based on the evaluation results on 23 students consisting of 17 items, the mean score of the assessment indicators obtained the lowest score of 2.7 and the highest score of 3.9 from the maximum score of 4.0 while the average number of scores of each item was 55.52. So, the average total score of $\frac{55.52}{17}=3.27$ from the maximum score of 4.0, so it falls into the category of "very decent / very good". 


\section{E. Evaluation}

Evaluation of the product as a learning medium is carried out after implementation, the aim of which is to correct deficiencies in the product as a learning media. The deficiencies in the product are corrected to increase the feasibility and quality of the development of interactive flash media in learning Newton's laws.

After carrying out the stages of media improvement in accordance with the advice of material experts, media experts, and 5 students in small group product trials, the next stage of the media is tried in large groups or field trials. Subjects in the field trials were all students of class VIII, amounting to 23 students, so that the average score of 3.27 was obtained from the maximum score of 4.0 , which was categorized as "very decent / very good".

Based on the average score of material validation, media validation, small group trials, and field trials, the average total score of interactive flash media in learning Newton's laws is 14.15. So, get a total average score of $\frac{14.15}{4}=3.54$ with a decent category. These averages and categories show that interactive flash media in learning Newton's laws is appropriate for use in the learning process. More details can be seen in table 13.

\begin{tabular}{|c|c|c|}
\hline Assessment & Respondents & Suggestion \\
\hline $\begin{array}{c}\text { Material Expert } \\
\text { Validation }\end{array}$ & 3.75 & Worthy \\
\hline $\begin{array}{c}\text { Media Expert } \\
\text { Validation }\end{array}$ & 4.12 & Worthy \\
\hline Small Group Trial & 3.01 & Worthy \\
\hline Field Trial & 3.27 & Very decent \\
\hline Total & $\mathbf{1 4 . 1 5}$ & \\
\hline Total Average Score & $\mathbf{3 . 5 4}$ & Worthy \\
\hline
\end{tabular}

Table 13:- Feasibility Results of Interactive Flash Media in Learning Newton's Laws

\section{CONCLUSSION}

Based on the results of the research and discussion, it can be concluded that the development of interactive flash media is categorized as suitable as a learning media in the learning of Newton's laws of science subjects. This can be seen from the results of the assessment of material experts worth 3.75 feasible categories, media experts worth 4.12 feasible categories, small group trials worth 3.01 worth categories, and field trials worth 3.27 very decent categories. So get a total average score of 3.54 which is included in the feasible category.

The use of media requires supporting infrastructure such as laptops or PCs. This infrastructure is recommended to be prepared before the learning process is carried out by the teacher. In addition, the application of interactive flash media widely by using many research subjects in various areas to prove the effectiveness of interactive flash media in improving student learning outcomes needs to be done in the future by future researchers.

\section{REFERENCES}

[1]. Arsyad, A. (2011). Media Pembelajaran. Jakarta: PT Raja Grafindo Persada.

[2]. Branch, R.M. (2009). Instructional Design: The ADDIE Approach. NewYork: Springer.

[3]. Djamarah, S.B. \& Zain, A. (2010). Strategi Belajar Mengajar. Jakarta: Rineka Cipta.

[4]. Fujiastuti, A., Wulandari, Y., \& Suwartini, I. (2019). Pengembangan Media Flash Berbasis Komik dalam Pembelajaran Menyimak Cerita Rakyat. Jurnal Teknologi Pendidika, Vol. 21, No. 3, 201-213.

[5]. Latuheru, J.D. (1988). Media Pembelajaran dalam Proses Belajar Masa Kini. Jakarta: Depdikbud DIKTI P2LPTK.

[6]. Madcoms. (2012). Adobe Flash CS6. Yogyakarta: Andi.

[7]. Munir. (2009). Multimedia Konsep dan Aplikasi dalam Pendidikan. Bandung: CV Alfabeta.

[8]. Muslich, M. (2007). Sertifikasi Guru Menuju Profesionalisme Pendidik. Jakarta: Bumi Aksara.

[9]. Rofiqah, S.A., Al-ghozali, A.Z., \& Ayatillah, L.A. (2018). The Development Of Flash-Based Physics Learning Media. International Conference on Mathematics and Science Education of Universitas Pendidikan Indonesia, Volume 3, 213-216.

[10]. Sari, W., Jufrida., dan Pathoni, H. (2017). Pengembangan Modul Elektronik Berbasis 3D Pageflip Professional pada Materi Konsep Dasar Fisika Inti dan Struktur Inti Mata Kuliah Fisika Atom dan Inti. Jurnal Edu Fisika, Vol. 02, No. 01, 38-50.

[11]. Siang, J.L., Sukardjo, M., Salenussa, B.J.M., Sudrajat, Y., \& Khasanah, U. (2020). Pengaruh Model Pembelajaran dan Kemampuan Berpikir Kreatif Terhadap Hasil Belajar IPA Siswa SMP. Jurnal Teknologi Pendidika, Vol. 22, No. 1, 40-52.

[12]. Sugiyono. (2015). Metode Penelitian dan Pengembangan (Research and Development/R\&D). Bandung: Alfabeta.

[13]. Widoyoko, E.P. (2014). Teknik Penyusunan Instrumen Penelitian. Yogyakarta: Pustaka Pelajar. 